Anna Haładyj*

\title{
Legal Grounds and Prospects for Public Participation in Climate Protection Projects - Polish Experience
}

\section{Podstawy prawne i możliwości udziału społeczeństwa w działaniach na rzecz ochrony klimatu - doświadczenia polskie}

http://dx.doi.org/10.12775/PYEL.2014.001

\begin{abstract}
The aim of this study is to answer the question which legal instruments enable the Poles to involve in issues concerning development (and later implementation) of the public policy on the climate change. Taking into account the mistrust towards
\end{abstract}

Doctor of Laws, Assistant Professor at the Department of Environmental Management Law The John Paul II Catholic University of Lublin. 


\section{Anna Haładyj}

the governmental authorities, as well as the underdevelopment of the Polish civil society, I assume that the level of the public participation in climate protection projects is low. The blame for this state of affairs is also to be put on the weakness of the legal instruments for the public participation in climate protection.

Key words: Public participation; adaptation; climate change; environmental law

\section{Streszczenie}

Celem niniejszego opracowania jest odpowiedź na pytanie, jakie instrumenty umożliwiają Polakom zaangażowanie społeczne w sprawy związane z kreowaniem (i późniejszym wdrażaniem) polityki publicznej w zakresie zmian klimatu. Z uwagi na deficyt zaufania do rządzących, oraz wciąż jeszcze niski poziom rozwoju społeczeństwa obywatelskiego w Polsce zakładam, że poziom uspołecznienia polityki ochrony klimatu jest w Polsce niski. Winą za to obarczam także słabość instrumentarium prawnego służącego gwarantowaniu społeczeństwu udziału w sprawach publicznych zakresu ochrony środowiska.

Słowa kluczowe: Udział społeczeństwa; adaptacja do zmian klimatu; prawo ochrony środowiska

\section{Introduction}

The statement that the society ought to be involved in the debate concerning the climate change is nowadays so obvious that it borders on truism. But the question is, whether the Polish society is, in fact, being involved in the decision-making processes aiming at climate protection? Does the Polish society want to acknowledge the facts connected with climate change and is the Polish society mature enough to face the awareness of the change? Do the governmental authorities want to announce the not-so-convenient truths about the climate change? These are all the questions that should be posed for the sociologists and political scientists to answer. The task of a lawyer is, in turn, to answer the question which legal instruments enable the society to become involved in shaping the public policies towards the climate change. 
The experiences gained during the Warsaw Climate Change Conference COP 2013 (11-22 November 2013), show that the stance of the Polish government on the climate change mitigation is clearly different from the expectations of other UNFCC parties. Moreover, the possibilities for the civic society to influence this stance are rather faint.

For this reason, it is worth considering whether the Polish society exerts any significant influence on adaptive actions (i.e. actions addressed to every one of us). My considerations are based on the analysis of the procedures established by the Strategic Adaptation Plan for vulnerable sectors and branches by 2020 and possibly by 2030 (henceforth: SAP 2020) ${ }^{1}$,

\section{In-between mitigation and adaptation to the climate change - prefatory considerations}

Every consecutive IPCC report defines the tendency towards global warming with an ever increasing certitude ${ }^{2}$ (yet, the temperature increases more rapidly in Europe in comparison to the global average rate). The reports also show the connection between this process and anthropogenic interventions ${ }^{3}$. So, the current state of scientific knowledge constitutes a starting point for answering the question, namely: how to counteract the climate change and what kind of actions to take in order to eliminate or suppress the adverse impact. The targeted actions can be divided into two groups: "strategies and measures to reduce greenhouse gas sources and emissions" (mitigation $\left.{ }^{4}\right)$ and

1 Strategic Impact Assessment of the strategic project of the adaptation plan for sectors and branches sensitive to climate change by 2020 and 2030 time horizon, March 2013, Final Version approved by the Minister of Environment. Source: http://www.mos.gov.p1/g2/big/2 013_03/60710b90a484b0929e70a7b35ce506af.pdf, par, 1.2 .

2 'Climate Change 2013, The Physical Science Basis', IPPC Working Group I.

3 'Climate change, impacts and vulnerability in Europe 2012', EEA Report 2012, No 12.

${ }^{4}$ An anthropogenic intervention to reduce the anthropogenic forcing of the climate system; it includes strategies and measures to reduce greenhouse gas sources and emissions and enhancing greenhouse gas sinks. Examples of mitigation measures are renewable energy technologies, waste minimization processes and public transport commuting practices, etc. Source: <http://climate-adapt.eea.europa.eu/glossary\#linkMitigation> (14.07.2014). 


\section{Anna Haładyj}

measurements moderating the effect of the climate change (adaptation ${ }^{5}$ ). The UNFCC ${ }^{6}$ Convention and the Kyoto Protocol provide the legal grounds for the abovementioned strategies and contain measures and objectives to reduce greenhouse gas emissions. The choice, manner and timing of those strategies are, to a great extent, determined by the political consensus, which, taking into account the prolonged validity of the Kyoto Protocol, is to be reached in 2015.

The implementation of the measures concerning the climate change is connected to changing the rules governing the social and economic aspects of life. This refers both to the greenhouse gas emission allowance trading scheme (as an exemplary mitigation strategy), and to adaptive strategies aimed at farming, transportation, spatial planning, etc.

The assessment of the legal mitigation strategies, including: the reduction of $\mathrm{CO} 2$ emission in the light of the EU law and policy, the implementation of the UNFCC Convention and the Kyoto Protocol, as well as civic actions towards the division of competences have already been repeatedly analysed in the bibliography ${ }^{7}$. That is the reason why this particular issue will not be thoroughly presented in the study. Yet, with reference to the prospective compromise, the society can express its views on reaching a compromise within the scope of mitigation measures. Nonetheless, the society will have no influence on the conditions of the compromise agreed upon by the parties - the international bodies competent for the international public law (the countries that were the signatories of the UNFCC Convention and the Kyoto Protocol).

The considerations taken from the legal point of view do not provide any specific legal instruments that ensure, or at least should ensure it, for the society to form opinions and exert influence on the climate change adaptation strategies. The climate change and the adaptation strategies are both issues that are of an enormous importance for the Polish society. These

5 Adjustment in natural or human systems in response to actual or expected climatic stimuli or their effects, which moderates harm or exploits beneficial opportunities. Various types of adaptation can be distinguished, including anticipatory, autonomous and planned adaptation. Source:<http://climate-adapt.eea.europa.eu/glossary\#linkAdaptation> 14.07.2014).

6 Ratified by Poland in 1996, Journal of Laws of 1996, No 53, item 238 and 239.

7 L. Karski, Renewable energy promotion: differentiating among large and small energy producers, in: Renewable Energy Law in the EU. Legal Perspectives on Bottom Up Approaches, eds. M. Peeters, T. Schomerus, Northampton 2014. 
issues not only broaden the general knowledge of the human-environment relationship and can change the attitudes and habits (and in this way fall within the scope of the environmental education), but they also (and above all) can require taking some far-reaching legal actions, such as issuing building ban within the flood-prone areas (these areas have been attractive building lots so far) or displacing the population from the areas under imminent danger.

This means that in practice the decisive influence of the society on the issues connected with the climate change is limited to the adaptation strategies, yet the adaptation as such increases its importance in politics and climate law $^{8}$. This particular approach results from both the UNFCC Convention and EU legal documents. The Convention as such aims at limiting the global temperature increase by reduction of the greenhouse gas emissions and emphasizes that the adaptation plays a pivotal part for the ecosystems to adjust to the climate change. Also, the climate change adaptation and the alleviation strategies have become one of the obligations of the signatory countries. [article 4 (1) point (b), (e), (f)]. The significance of the adaptation strategies is also to be emphasized by the fact that in 2010, during COP16 Cancun, Mexico, the parties agreed upon the so called Cancun Adaptation Framework (CAF) - an Adaptation Committee was established in order to oversee the actions falling within the scope of the Convention. The decision was taken on the works on the National Adaptation Plans for the underdeveloped countries, which are to facilitate the adaptation to the climate change. Moreover, a new programme concerning the losses and damages resulting from the impact of the climate change was developed.

Similar purpose led to the compilation of the "White Paper: Adapting to climate change: Towards a European frameworkfor action COM(2009)147", in which the EU defined the scope of action for the years 2009-2012 and the "EU Strategy on adaptation to climate change COM(2013) 216 final"10. Both documents emphasize the importance of adaptation actions in a spirit

8 See further elaboration by J. Ciechanowicz-McLean, Zasady prawa klimatycznego, Gdańskie Studia Prawnicze 2010, No XXIV; see also L. Karski, Climate Law in Poland - towards an overall regulation, in: Climate Law in EU Member States: Towards National Legislation for Climate Protection, eds. M. Peeters, M. Stallworthy, J. de Cendra de Larragan, Northampton 2012, p. 231-258.

$9 \operatorname{COM}(2009) 147$ final.

$10 \mathrm{COM}(2013) 216$ final. 


\section{Anna Haładyj}

of sustainable development. Although the documents do not address the issue of the public participation in the adaptation actions, it seems, such actions are, per se, (by means of references to sustainable development and to the access to information about the climate change), axiologically directed toward both of these documents. In addition, the ratification procedures regarding these documents are convergent with the policy of good governance and are subjected to an ever increasing popularity in the society ${ }^{11}$.

Having analysed the normative background, I think it would be right to pose the question about the way in which the Polish society can participate in the public debate concerning the climate change adaptation. The analysis will be carried out on the basis of interpretation of the legal grounds referring to the public participation in environmental protection in connection with the ratification procedure for the Strategic Adaptation Plan (SAP 2020).

The question is crucial for formal reasons. On 11-22 November 2013 Poland hosted the COP19 in Warsaw, which was understood as the preparation for mitigation measures ${ }^{12}$ in the post-Kyoto period ${ }^{13}$. Moreover, on 29 October 2013 the Council of Ministers approved of the Strategic Adaptation Plan, which had been developed in response to the EU

11 See EU website <http://ec.europa.eu/clima/policies/adaptation/what/docs/ background_report_part2_en.pdf >, accessed 18 May 2014: "For complex and socially relevant issues - such as climate change adaptation - a broad discourse with stakeholders is important for the policy - making process to enhance its quality of the content and the implementation success. Thus, stakeholder involvement with the aim to raise awareness, provide relevant information and gather expectations and needs are important elements in the development process of the EU Adaptation Strategy. From January 2012 to the end of October 2012, stakeholder involvement activities to support the development of the EU Adaptation Strategy were carried out on two levels: (i) stakeholder involvement with different Commission Services, Member States, private sector and stakeholders for specific themes and (ii) public consultation via the online consultation on 'Your Voice in Europe'(...). To involve the broader public, a public consultation was carried out by DG CLIMA with the objective to collect opinions from stakeholders and experts in the field of adaptation to climate change. The "Consultation on the preparation of the EU Adaptation Strategy" was open from 21.05.2012-20.08.2012 on the website 'Your Voice in Europe'."

12 In respect of mitigation, the Polish Presidency set inter alia the priority: "Building up confidence in the process - giving Parties and other stakeholders a sense that negotiations are delivering and moving in the right direction with all on board", Source: < http://www. cop19.gov.pl/incoming-polish-presidency-of-cop19.> (14.07.2014)._Whereas no objectives were set in respect of social communication procedures for the climate change adaptation.

13 On the perspectives of the post-Kyoto period see also: S. Boeters et al., Post-2012 Climate Policy Scenarios, Netherlands Environmental Assessment Agency 2007. 
call for preparation of the national adaptation strategies. The abovementioned question is well-justified also for axiological reasons. It can justify the public actions that are performed on the basis of the sustainable development policy, and those that are legally based on the Aarhus Convention and the EU directives on the public participation in environmental protection.

For the purpose of this study I have put forward a working hypothesis that the involvement of the Poles in the issues connected with the climate change is not high, and that one of the reasons for this state of affairs is the weakness of the legal instruments which could enable the society to participate in the processes of designing public policies.

The attempt to answer the abovementioned question should begin with presentation of the legal instruments aimed at facilitating the public participation in environmental protection with reference to the adopted plans and programs concerning the climate change.

\section{Legal grounds for the public participation in the adoption of strategic planes and programmes}

Fulfilling the provisions of the Aarhus Convention and Directive 2001/42, Poland normalized the Strategic Environmental Assessment, along with the public participation with reference to the "plans and programs" in the light of article 2 point (a) of Directive 2001/42. Extending the statutory regulations about "policies" and "strategies" and thus setting guidelines for the future political actions. Within the framework of the Polish legal system, these regulations have the nature of strategic (and long-term) planning papers at the highest possible level of generality.

In Poland, the public participation in the adoption of any strategic papers (including plans, programs, strategies and policies) has always been governed in two ways. Firstly, the public participation procedures have been linked to the Strategic Environmental Assessment, in which the participation is viewed as: (1) the opportunity to take cognizance of the 'essential' papers, and (2) the possibility to submit comments and proposals 'within 21 days' (3) to obtain knowledge of the adoption of the document, and any observations and conclusions which have been made.

The catalogue of the papers, which require (or can require) the Strategic Environmental Assessment is specified in the "Act on providing information 


\section{Anna Haładyj}

on the environment and environmental protection, public participation in environmental protection and on environmental impact assessment"14, by means of implementing article 3 of Directive 2001/42.

The second category of the legal grounds entitling the society to participate in the process of strategic paper adaptation is provided by specific provisions of specific acts which clearly indicate that the society have the right to participate in the adoption of any strategic paper.

In addition, the acts either refer directly to the procedure of making observations and conclusions within the light of the Strategic Environmental Assessment, stating that the competent authorities "provide for the public participation, on the principles and procedures set forth by the Act of 3 October 2008 on providing information on the environment and environmental protection, public participation in environmental protection and on environmental impact assessment in the proceeding", the object of which is the adoption of a document, or frame their own modes of submitting comments and requests, having different deadlines and modes of application.

One example of a draft paper, in making of which the public participation is based on the provisions of the Strategic Environmental Assessment, is the adaptation of the state environmental policy, as well as the environment programmes adopted at the level of gmina (communes or municipalities), powiat (counties or districts) and voivodeship (provinces), i.e. the units of administrative subdivision in Poland. The specific rules and procedures concerning the public participation are framed in such documents as the draft study of the land use conditions and directions, the draft of local spatial planning, and the draft specifying the conditions of heat, electricity and gas fuels supply in municipalities.

The Polish Strategic Environmental Assessment was based on the model available in the EU law. The model was subjected to formal procedures ${ }^{15}$, which usually were different form the procedures of framing the draft projects or plans. This approach was based on the research results and specific surveying methods, as well as meticulously described methodology, which allowed to describe the environment in strictly measurable and

14 Journal of Laws of 2013, item 1235.

15 Imperial College London Consultants Report, 'The relationship between the EIA and SEA Directives', August 2005. 
scientific categories ${ }^{16}$. For this reason, taking into account that Strategic Environmental Assessment is, in fact, a highly formal process and it constitutes a purely formal instrument, it is rather obvious that the public participation in this assessment is regarded as an indispensable element of the procedure. There is hardly any space for any reflection on the role of the society or the ethical or the axiological reasons for their involvement.

In practice, the implementation of this kind of assessment in Poland is based on the assumption that the society participates in the process only at the stage in which the draft papers are formed and there is already a preliminary environmental impact assessment.

This means that the procedure which ensures that the society can "express their opinion about draft projects and programmes and the attached reports on the environment before the given project or programme is being approved" is, in fact, limited to the possibility of reviewing the draft project and the environmental impact assessment and expressing the comments or remarks "at least 21 days". The regulations do not state precisely if there are any prerequisites for extending the deadline, leaving this issue for the competent administrative body to decide.

It is possible - and such situations have already occurred - that if the nationwide public consultation of a draft concerning the issues vital for the whole society, and being implemented on a national scale, and/or controversial, the administrative body fixed the deadline of 21 days. Such situation arose when the draft of the Polish Nuclear Power Programme, which defined the support for investments in nuclear power was issued. The project did not only cover issues such as the development of human resources, profiled training courses, support for institutions, but also pinpointed the possible locations for the power plants. However, at the same time, it did not contain any political decision about the choice of nuclear energy as the source for covering the demand for electricity in Poland. Such a decision had been taken several years beforehand ${ }^{17}$. The Minister of Economy had fixed the 21-days-long deadline for the public participation in the Strategic Environmental Assessment during the end-of the-year

16 J. Jendrośka, Ocena strategiczna w Polsce: odrębna procedura czy integralna część procesu planowania? Obowiqzująca regulacja prawna w świetle doświadczeń z ocenq strategicznq narodowego Planu Rozwoju, Problemy Ocen Środowiskowych 2004, No 1, p. 3.

17 The Resolution no. 157/2010 of the Cabinet of 29 September 2010 regarding the Polish Energy Policy by 2030, The Polish Energy Policy by 2030 (Attachment). 


\section{Anna Haładyj}

festive period and Christmas, which is traditionally a time of winter holiday. It was only under the pressure of the non-governmental bodies that the deadline had been extended to three months ${ }^{18}$.

The regulations do not provide for the possibility (nor do they exclude it) of the second procedure in case there are significant changes in the content of the document under review. These two paradoxes mirror the weakness of the Polish legal instruments aimed at ensuring the public participation in the adoption of public policies, including those relating to the climate protection. This could be remedied by the office workers highly-trained in soft skills. Nonetheless, the implementation of the public governance principles still constitutes a challenge for the office workers.

However, the experts in the Strategic Environmental Assessment are well-acquainted with the British model of the so called policy appraisal ${ }^{19}$. This model is also used at the EU level for the assessment procedures within the frames of the so-called Cardiff process ${ }^{20}$, and also those governing the use of the European Funds.

This model departs from the measurable data obtained by scientific methods and favours setting goals and evaluating their implementation (and not their direct impact on the environment) ${ }^{21}$. This model is much more focused on connection between the Strategic Environmental Assessment and the decision-making process. In this way, it becomes an integral part of the decision-making process, rather than a part of a procedure that must be strictly conducted. In Poland this model can be applied whenever the Strategic Environmental Assessment is done for documents that do not require this procedure in the light of law; i.e. does not constitute the basis for future investments. Then, the authorities deciding on the range of the

18 Source:<http://www.mg.gov.pl/files/upload/19257/2013_10_14\%20PPEJ\%20Prezen tacja.pdf > (14.07.2014).

19 This model was applied, for instance, to the assessment of the National Development Plan 2004-2006, conducted in 2004 by a group of independent experts from the Regional Ecological Centre for the Central and Eastern Europe (REC). The related experience, assumptions and procedure are described by: J. Jendrośka, Ocena strategiczna w Polsce: odrębna procedura czy integralna częś procesu planowania? Obowiq̨zująa regulacja prawna w świetle doświadczeń zocenq strategicznq narodowego Planu Rozwoju, Problemy Ocen Środowiskowych 2004, No 1, p. 7-9.

20 Communication from the Commission to the European Council - Partnership for integration - A strategy for Integrating Environment into EU Policies - Cardiff - June 1998, * COM/98/0333 final

21 Ibidem, p. 4. 
assessment of the environmental impact of the document, can approve of the "policy appraisal" model. This model was adopted within the Strategic Environmental Assessment for the draft of the strategic adaptation project for the sectors and branches vulnerable to the climate change by 2020, with the prospect of 2030 (hereinafter: SAP 2020) ${ }^{22}$ as the document that sets out the frameworks and development trends of the various processes in the social, economic, legal, environmental sphere, and does not constitute the point of reference for the investment decision purposes.

At the same time one cannot forget that the policy appraisal model places greater emphasis on the decision-making process, which results from the implementation of the assessed document. For this reason, the question about the legal basis and the specific tasks connected with the process of adopting the SAP 2020 is entirely appropriate.

\section{The procedure of preparation and adoption of SAP 2020}

The Polish government reacted to the adoption of the White Paper: Adapting to climate change: Towards a European framework for action $\operatorname{COM}(2009) 147$ on March 19, 2010 taking the decision on the need to develop adaptation strategies. The decision was implemented on 29 October 2013. Judging by the content of the SAP 2020, its main objective was to ensure the sustainable development and the efficient functioning of the economy and society in the face of the climate change (p. 34). This objective was broadly defined and as one can easily notice, was also addressed to the society. Still, had the society participated in the creation of the document, in formulating its objectives and implementation instruments, and in the very Strategic Environmental Assessment as such?

The assumptions about the works on the SAP 2020 presented by the Ministry of Environment were the following: on the basis of the results of a more extensive research project called KLIMADA conducted in 20112013 by the Institute of Environmental Protection - the National Research

22 Strategic Impact Assessment of the strategic project of the adaptation plan for sectors and branches sensitive to climate change by 2020 and 2030 time horizon, March 2013, Final Version approved by the Minister of Environment. Source: http://www.mos.gov.p1/g2/big/2 013_03/60710b90a484b0929e70a7b35ce506af.pdf, par. 1.2.(14.07.2014). 


\section{Anna Haładyj}

Institute, the Ministry of Environment started the preparation of the conceptual framework, structure and the preliminary draft of the SAP (spring-summer 2012). From October till December 2012, the internal arrangements were made. In December 2012 a draft SAP 2020 was approved by the Ministry of Environment and was transferred to the interministerial consultations. The consultations, the Strategic Environmental Assessment and the public consultations took place from January to April $2013^{23}$. In the summer of 2013, the SAP project was approved by the collegial bodies working by the Council of Ministers, including the Joint Commission of the National and Local Government ${ }^{24}$ and on 29 October by the Council of Ministers. The stage of the arrangements is the key stage for the assessment of the public participation in the process of creating the strategy, its objectives and implementation instruments.

According to the provisions of the Working Regulations of the Council of Ministers ${ }^{25}$, each draft of a governmental document (including the designed strategy) shall be subjected to the process of consultations and agreements. The most essential elements are hidden in the key words, such as: "internal arrangements" and "interdepartmental". "Internal arrangements" means that the draft document is agreed upon by the members of the Council of Ministers and the Head of the Chancellery of the Prime Minister, and, in legal terms, in agreement with the Government Legislation Centre (article 12(1)), and the Joint Commission of the National and Local Government (article12(3)).

The decision to refer the project to the opinion of other state administration bodies, social organizations and other entities and institutions is taken by the applicant authority, in this case, the Minister of the Environment (article 12(5)). In addition, the inter-ministerial consultations encompass the process of obtaining the opinion of other public authorities. As it can be observed, in any case the project is subjected to a wider popularization or public debate.

23 Source:<http://www.mos.gov.pl/artykul/5231_konsultacje_spoleczne/20110_konsulta cje_spoleczne.html> (14.07.2014).

24 S. Tumielewicz, Strategiczny Plan Adaptacji dla sektorów i obszarów wrażliwych na zmiany klimatu do roku 2020 z perspektywq do roku 2030 (SPA 2020). Source:<https:// klimada.mos.gov.pl/wp-content/uploads/2013/10/Strategiczny-plan-adaptacji-dlasektor\%C3\%B3w-i-obszar\%C3\%B3w-wra\%C5\%BCliwych-na-zmiany-klimatuSTumielewicz.pdf> (14.07.2014).

25 The Resolution no. 49 of the Cabinet of 19 March 2002, Monitor Polski of 2002, No 13, item 221 with amendments. 
In contrast, "public consultation" encompasses the stage of the Strategic Environmental Assessment once the primary environmental impact of the project has already been assessed.

For the project SAP 2020, the strategic impact assessment was adopted on March 7, 2013 and was made available on the website of the Ministry of Environment. The society was given the opportunity to review the documentation of the case and to submit comments and requests.

At that time, 230 both general and detailed comments and requests were made. They were arranged in a table and, in a form of an appendix, available on the website of the Ministry of Environment ${ }^{26}$. The analysis of those comments and requests led to the conclusion that the majority of the comments had been submitted by the public authorities. Whereas the two (!) natural persons were represented by the context of their workplace for example, by the Department of Meteorology and Climatology at the University of Lodz and by the Institute of Geophysics at the Warsaw University. How many natural persons or members of the public made comments and requests in this process? None.

\section{The evaluation of the public participation in the adoption of the SAP 2020 - the analysis of the applied provisions}

What does it mean? Firstly, bearing in mind the fact that the strategic assessment was conducted on the basis of the "appraisal policy", one may assume that the society was involved in the process of shaping the assumptions and objectives of the document, and had the right to express their views on the main objectives and the hierarchy of the detailed objectives. Yet, the analysed procedures of the Council of Ministers did not provide for such an obligation (although they did not exclude such a possibility), and the website of the Ministry of Environment devoted to the Strategic Environmental Assessment did not reveal any trace of such activities. That meant that the fundamental assumption about framing

26 Source: <http://www.mos.gov.pl/g2/big/2013_08/1d63d4c130cf6d9a99d7a330273cb b8f.pdf> (14.07.2014). 


\section{Anna Haładyj}

a document applying the model of appraisal policy was flawed. Thus, with reference to the model, the strategic assessment applied only to the concept of the methodological assessment of the document, and not the procedures of framing the document. In fact, this reason was not at all mentioned in the environmental impact assessment.

Secondly, the lack of public involvement in the submission of comments and requests could have been caused by the ignorance of the fact that such a document was being framed and of its significance for an average citizen. This ignorance could, on one hand, result from the lack of public debate and, on the other hand, some procedural errors might have been committed if the document had not been made publicly known. According to the information available on the website of the Ministry, the document was published only on the website. If that was the case, some critical remarks must be made. The legal definition (article 3(1) point 11) of the Act on Access to Information) states that making the document publicly available includes, in addition to announcing this fact on the Public Information Bulletin, publishing it in the press suitable for the type of the document. On the website of the Ministry of Environment, there was no information whatsoever about making such a notice in the national press.

Thirdly, it is difficult to assess the draft of a document based on the project and a strategic impact assessment, and not to analyse the whole accompanying material including: the assumptions about the document, the documents providing the legal basis of it (the EU Strategy), and the results of the consultations with environmental authorities (the General Director for Environmental Protection and the Chief Sanitary Inspector), as well as internal and interdepartmental arrangements. The rules of praxeology and pure logic dictate that a process of consultation should be preceded by transferring the documents to public consultation, otherwise it should be repeated after changes are made as a consequence of internal and interdepartmental arrangements. It is hard to resist the impression that public consultations were held concurrently with these arrangements.

The fact that the documentation (although as noted: the incomplete documentation) was made public on the internet, is the undeniable advantage of the analysed proceedings of the public participation. There was no need to visit the seat of an administrative body in order to familiarize oneself with the document, which obviously and unmistakably pays tribute to the use of ICT, just like the possibility to submit the comments and requests electronically (permitted by law). Finally, one should notice and 
appreciate the extended deadline for the submission of comments and requests over the statutorily provided minimum, i.e. from 21 to 41 days (counting calendar days, including 28 week days).

However, that does not change the fact that the period, though extended beyond standards - was too short to inform a larger group of potentially public concerned about the procedure and the possibility to submit comments and requests.

In accordance with the provisions of the "Act on Access to Information (...)" on approving the document, the authority should make reference to the comments and requests, indicating which of them were found welljustified and why, and which were refused. In this case, the answers were very brief: "Comment declined. This is not the stage." In some cases, it seemed downright offensive. Another issue is the failure to take account of the need to protect the personal data of abovementioned individuals who have submitted the comments and requests on behalf of specific institutions.

There is yet another advantage of the procedure which is worth emphasising. During that period, a half-day conference was held in Warsaw, in order to address those issues. It was also a significant step forward in the form of additional measures, and in terms of publicity. Nonetheless, the duration and location of that event (it should have included a series of meetings in all provinces, after all, a lot of provisions were to be implemented on regional and local levels) seemed insufficient and causes dissatisfaction.

Finally, it must be stated that this type of project, taking into account its fundamental importance in the field of adaptation actions, affects not only the current manners of framing regulations (change of the legal instruments, giving a higher rank to the instruments neglected so far, such as spatial planning or flood management), but also those within the sphere of the legally protected values, such as property rights (e.g. the ban on home building within the flood-prone areas).

The work on such a document should be accompanied by a series of events promoting not only the knowledge about the proposed document, but also - and perhaps above all - about the climate change. The authors of the Strategic Environmental Assessment purport that "the present social attitudes clearly show the model, which expresses scepticism to any research indicating that people are to blame for the climate change, as well as the belief that any actions combating climate change pose threat to the Polish economy and are connected with costs rather than benefits, and 


\section{Anna Haładyj}

also the reluctance towards action in the direction of a low-carbon economy or blaming the EU climate policy for the increases in energy prices" ${ }^{27}$.

Of course, one can, in a sense, justify the lack of these types of actions with their high costs, but if the environmental protection (including climate protection) is the responsibility of the public authorities, the public resources (just like in the case of the campaign "Explore the atom" ${ }^{28}$ ) should be planned adequately.

\section{Conclusions}

There is no doubt that the methods and organization of the public authorities in relation to the risks, should be quite different from the actions taken in the event of natural disasters. However, it does not mean that the actions taken by the public authorities at times of risk (that is, for example, preparing the society to adapt to the climate change) can only be simulated. At the same time, the studies show that when the threat seems distant, the interest in potential danger decreases. I think that nowadays such social attitude is also common in Poland. The main conclusion of the presented analysis is obvious - the public participation in the framing of SAP 2020 was limited, or stating it more bluntly, non-existent. This means that the procedure dispelled the hopes, both in terms of improving the quality of the document, and education.

I assume that the Polish society en masse neither has the knowledge about the adoption of SAP 2020 and the subsequent actions to be taken in the future, nor what was already mentioned above, has the sufficient knowledge about the anthropogenic causes of the climate change. This is a rather ominous sign for the implementation of the SAP 2020, which should be accomplished by the transposition of specific actions to documents relating

27 Strategic Impact Assessment for the Strategic Project..., p. 18. This situation has not changed much since 2000, when the arguments of insufficient ecological social awareness of greenhouse gas reduction. See: Z. Karaczun, A. Kassenberg, M. Sobolewski, Polska wobec postanowień Konwencji Klimatycznej, Instytut na rzecz Ekorozwoju, Warszawa 2000 p. 43-44, cit. after T. Burger, Świadomość ekologiczna spoteczeństwa polskiego u progu XXI wiek. Instytut na rzecz Ekorozwoju, Report No 1/2000. Institute for the sustainable development, Warszawa 2000.

28 Source: http://poznajatom.pl/. 
to regional and, in particular, local development. The provisions relating to the climate change adaptation can become a part of a number of local papers or strategies for sustainable development. The society, not knowing the methods, the causes and effects of adaptation might not be interested in participating in this type of participatory procedures at the local level. Of course, conducting educational campaigns could be required, but local governments, as decentralized entities, may conduct these activities to varying degrees and in different ways (including situations in which they will not conduct them at all). I believe that informing the Poles on the climate change and possible adaptation measures should be a fundamental objective of the environmental education implemented on a national scale by the Ministry of Environment, within the scope of its objectives.

To conclude, it is worth emphasizing that the documents accepted on the local level do not always have to be subjected to the Strategic Environmental Assessment ${ }^{29}$. Thus, in the face of the absence of any applicable laws relating to consulting the projects with local communities (such provisions do not apply to the document of any kind), we have to deal with a situation in which some of the documents providing for adaptation to the climate change in general may skip the proceedings encompassing social participation (e.g. municipal housing stock - the context of thermal improvement projects). That is a glaring contradiction to the provisions of the documents and acts referred to in the first paragraph. Yet, first and foremost it contradicts the axiology of sustainable development. Also, it is regrettable that the good practices catalogue, presented on the website of the European platform of climate change adaptation (Climate - $\mathrm{ADAPT}^{30}$ ) is not at all implemented by the Polish government, which challenges the effectiveness of the solutions adopted in this mode of action.

To conclude: ten years ago some national Case Studies were presented by REC in the study "Aarhus meets Kyoto" ${ }^{31}$. Describing Polish Case Study the authors presented the following point of view: "The government's efforts to promote knowledge and ensure cooperation in the implementation

\footnotetext{
29 See: D. Palekhov, M. Schmidt, Implementing SEA as an instrument for Devising regional Sustainable Development, in: Sustainable Development on the national, regional and Local Level - Polish Experiences and their possible Implementation in Ukraine, eds. S. Kozłowski, A. Haładyj, Lublin 2006.

30 Source: <http://climate-adapt.eea.europa.eu/>.

31 F. Rizzo et al. (eds.), Aarbus meets Kyoto. National Case Studies in central and Eastern Europe on Public Participation in Climate Change Related Decision Making, Szentendre 2003.
} 


\section{Anna Haładyj}

of climate policy reveal that the only source of information on this subject is the website of the Executive Office for Climate Convention" ${ }^{32}$. Moreover, "consultations have limited scope, and no consultations are conducted with respondents, non-governmental organisations or other groups that could be interested in." A decade later the conclusion remains the same.

\section{Bibliography}

Boeters S. et al., Post-2012 Climate Policy Scenarios, Netherlands Environmental Assessment Agency 2007.

Ciechanowicz-McLean J., Zasady prawa klimatycznego, Gdańskie Studia Prawnicze 2010, No XXIV.

Climate change, impacts and vulnerability in Europe, EEA Report 2012, No 12.

Climate Change 2013, The Physical Science Basis, IPPC Working Group I.

Jendrośka J., Ocena strategiczna w Polsce: odrębna procedura czy integralna część procesu planowania? Obowiązująca regulacja prawna w świetle doświadczeń z oceną strategiczną narodowego Planu Rozwoju, Problemy Ocen Środowiskowych 2004, No 1.

Karski L., 'Renewable energy promotion: differentiating among large and small energy producers', in: Renewable Energy Law in the EU. Legal Perspectives on Bottom Up Approaches, eds. M. Peeters, T. Schomerus, Northampton 2014.

Karski L., 'Climate Law in Poland - towards an overall regulation', in: Climate Law in EU Member States: Towards National Legislation for Climate Protection, eds. M. Peeters, M. Stallworthy, J. de Cendra de Larragan, Northampton 2012.

Palekhov D., Schmidt M., 'Implementing SEA as an instrument for Devising regional Sustainable Development', in: Sustainable Development on the national, regional and Local Level - Polish Experiences and their possible Implementation in Ukraine, eds. S Kozłowski, A. Haładyj, Lublin 2006.

Polska wobec postanowień Konwencji Klimatycznej, eds. Z. Karaczun, A. Kassenberg, M. Sobolewski, Instytut na rzecz Ekorozwoju, Warszawa 2000.

Burger T., Świadomość ekologiczna spoteczeństwa polskiego u progu XXI wieku, Report 1/2000, Warszawa 2000.

Rizzo F. et al. (eds.), Aarbus meets Kyoto. National Case Studies in central and Eastern Europe on Public Participation in Climate Change Related Decision Making, Szentendre 2003. 
Legal Grounds and Prospects for Public Participation...

'The relationship between the EIA and SEA Directives', Imperial College London Consultants Report, August 2005.

Tumielewicz S., Strategiczny Plan Adaptacji dla sektorów i obszarów wrażliwych na zmiany klimatu o roku 2020 z petspektywq do roku 2030 (SPA 2020), https:// klimada.mos.gov.pl/wp-content/uploads/2013/10/Strategiczny-planadaptacji-dla-sektor\%C3\%B3w-i-obszar\%C3\%B3w-wra\%C5\%BCliwych-nazmiany-klimatu-STumielewicz.pdf

\section{Email}

ahaladyj@kul.pl 